Revista de la red interuniversitaria de estudios sobre las literaturas rioplatenses contemporáneas en Francia

$9 \mid 2013$

Homenaje a Ana María Barrenechea

\title{
Una santa reunión de palabras
}

Mariana Di Ció

\section{OpenEdition \\ Journals}

Edición electrónica

URL: http://journals.openedition.org/lirico/1205

DOI: 10.4000/lirico.1205

ISSN: 2262-8339

Editor

Réseau interuniversitaire d'étude des littératures contemporaines du Río de la Plata

\section{Referencia electrónica}

Mariana Di Ció, « Una santa reunión de palabras », Cuadernos LIRICO [En línea], 9 | 2013, Publicado el

01 septiembre 2013, consultado el 22 septiembre 2020. URL : http://journals.openedition.org/lirico/ 1205 ; DOI : https://doi.org/10.4000/lirico.1205

Este documento fue generado automáticamente el 22 septiembre 2020

\section{(c) (i) (9)}

Cuadernos LIRICO está distribuido bajo una Licencia Creative Commons Atribución-NoComercialSinDerivar 4.0 Internacional. 


\section{Una santa reunión de palabras}

\section{Mariana Di Ció}

\section{REFERENCIA}

Arnaldo Calveyra. Poesía reunida, $2^{\mathrm{a}}$ edición aumentada (Incluye El cuaderno griego y el libro inédito Diario del recluta), Buenos Aires, Adriana Hidalgo, 2012, 653p. 
1 En el medio de un camino de hojas secas y bancos vacíos, una silla. Y la mirada de perfil del hombre del Luxemburgo, clavada en algo que se escapa de nuestro ángulo de visión. La foto de Daniel Mordzinski en la tapa de esta Poesía reunida introduce a un Arnaldo Calveyra en quien conviven, con toda naturalidad, "flores de tinta" y "silencio de fábrica". Porque a pesar de los once libros y más de 650 páginas que nos ofrece esta cuidada edición de Pablo Gianera y Daniel Samoilovich -responsables también de una extensa cronología que entremezcla datos factuales con fragmentos de reseñas y de entrevistas al autor-, la poesía de Calveyra está plagada de silencios e historias subterráneas.

2 Además del mérito inmenso de acercarnos a textos que hasta no hace mucho era más

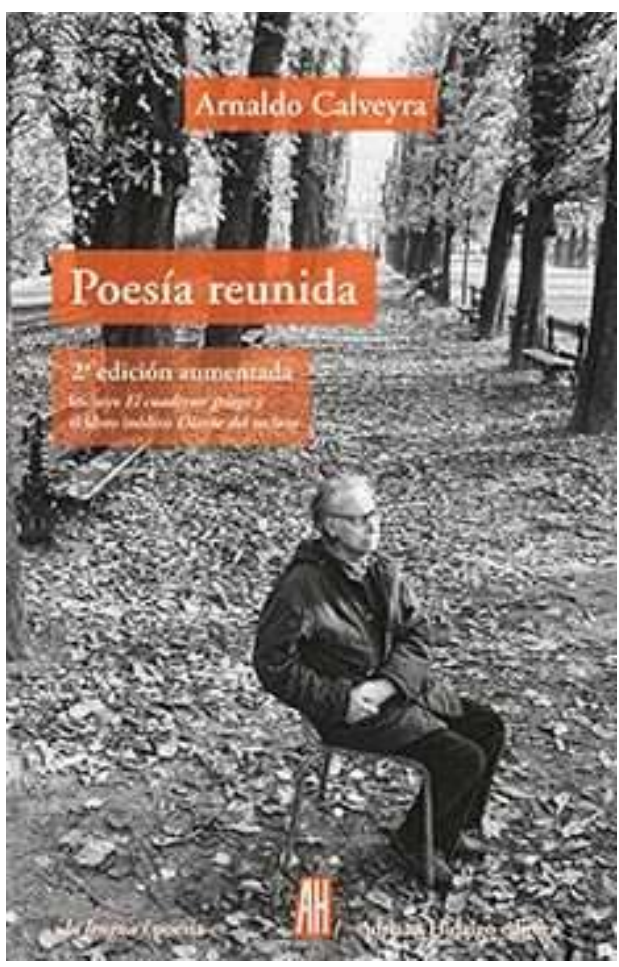
fácil hallar en francés que en español, esta segunda edición nos permite explorar un poco más las raíces del jardín primitivo en donde abreva Calveyra, donde las resonancias adánicas cohabitan con la cultura griega y las tragedias shakespearianas. Son "huellas del paraíso ruidosas de caídas", donde todo "huele a alfalfar pero sin las mariposas", y las "lluvias ahogadas" dejan paso a "ganas de horizonte / el testamento de las abejas". Entre los textos que se incorporan a esta segunda vuelta, El cuaderno griego (publicado en el Diario de Poesía en 2007) y un diario escrito cuando esperaba la revisión médica para el servicio militar y al que llamó "medio en broma", Diario del recluta.

3 Cada uno a su modo, estos dos libros revelan los cimientos de una escritura en permanente gestación, donde la formación clásica de Calveyra se confunde con "la mañana del cuartel con un gusto a sílaba rancia en la boca" que nace en las cercanías del río Paraná. El tiempo pasmado del mito se intercala en los trabajos y los días del poeta, del fumigador, del conscripto, del viajero: "Vuelves de nuevo a ser aquel hombre antiguo, su quedar a dos horas del crepúsculo, momento indeciso. $\mathrm{Y}$ ahora de nuevo y de golpe la ciudad, su puerto, la gente que se echa a deambular por las calles, el ruido y una canción de ciudad. / Un durmiente acaso, acaso alguien que va dormido entre dos hileras de paraísos. Porque al dormido, ¿qué más da que el tiempo vaya o vuelva ?".

Efectivamente, el tiempo va y vuelve en Calveyra, que parece saltar a la rayuela con la cronología. Porque todos sus textos son, en realidad, ejercicios con el tiempo, que discurre y se entrecorta como "una orquesta en viaje al diminuendo", y que da marcha atrás solo para volver a comenzar. Porque el tiempo de la publicación o de la traducción encubre y vela el tiempo de la escritura : cada texto esconde o encierra una doble o a veces triple cronología (la de la traducción, la de la escritura, la de la publicación) que permite hilvanarlos de manera diferente y a la vez simultánea : el colofón del Diario del fumigador de guardia indica, por ejemplo, “Ensenada, 1951-París, 1983" pero, como muchos de los libros de Calveyra, fue publicado primero en francés (1987) y recién en 
2002 en español. Anexar a la producción conocida un libro temprano y, a la vez, un último eslabón supone, entonces, una vuelta de tuerca suplementaria: al dislocar las coordenadas espacio-temporales, lo circunstancial queda en el tintero, mientras que la escritura se asienta en "el maná del presente". El volumen se cierra con una nota seca, en clave burocrática, que contrasta con el asombro del amanuense que registra los pequeños milagros cotidianos ("hacer estas notas para conservar aunque más no sea algunas") y que marca también el enrolamiento del conscripto: "Fecha de incorporación : 15 de marzo de 1950". Y si la fecha resulta, hoy, más anecdótica que anacrónica, lo cierto es que el final del Diario del recluta también inaugura una estación nueva, proyectada hacia caminos que son antiguos y que a la vez están todavía por reescribirse.

5 Como la escarpada y cambiante geografía griega que recorre y describe, las palabras de Calveyra registran altos en el camino y entrevistas con el mar, las piedras de Epidauro y la luminosidad radiante del "día sin hiatos". Cada poema supone una variación en la intensidad y la medida del metro, donde anapestos y dáctilos se alinean con la cadencia fluctuante de la prosa, donde la severidad de los géneros se disuelve en anábasis, apuntes, diarios, cartas, cuadernos y escenas de teatro que retratan la penetrante topografía de paisajes improbables y que, al sumarse, configuran ese "alfabeto de poema de viaje" que es toda su obra.

6 Si el ritmo y las palabras parecen indisociables del paisaje ("Después de leguas, una coma"), también la reflexión metapoética infiltra cada línea de este devocionario personal : "Dejar que la pluma corra, dejar correr la pluma a través de esta sensación de tiempo afuera -la trama de la mañana es una cobija tejida al telar-, hacer con ella escritura como otros hacen fuego con dos piedras". No sorprende, entonces, que Saer haya sugerido que el Diario del fumigador de guardia puede leerse sustituyendo la palabra "rata" por la palabra "poesía". Porque aun en las palabras aspiradas y el timbre amortiguado de ciertas armonías, sospechamos la mano del poeta que lucha cuerpo a cuerpo con la lengua, que sabe "tomarle la temperatura" a las palabras para mejor indagar "en la plena lividez del paréntesis".

7 Como el escudo de Aquiles, las mil historias que cuenta la poesía de Arnaldo Calveyra también descansan en la circularidad de un tiempo y de un espacio que se metamorfosean y renuevan con cada lectura, de un tiempo y un espacio que son progresivamente isla, río, muelle, paisaje antediluviano o jardín parisino, y que el lector ve forjar ante sus ojos mediante la invocación de voces cotidianas y "palabras fuera de uso, al borde de la plegaria". Porque a pesar de las hojas de otoño en las que está sentado Calveyra, su Poesía reunida es, en realidad, un breviario o misal (¿maizal ?) gregoriano, iniciación a la "religión de la mirada", puerta de acceso a una "santa reunión de palabras", llamada a desafiar las leyes de gravedad poética para volver siempre a recomenzar: "He caminado un centímetro y habré pensado cien años. Mientras escribo, me parece que voy de aquí a aquí con una lanzadera llena de palabras, cada una de ellas bien empleada podría llegar a ser una bota de siete leguas pero con el mero salto destrozar la tela tan pacientemente urdida". 


\section{AUTORES}

MARIANA DI CIÓ

Université Paris III-Sorbonne Nouvelle 